\title{
UMA VISÃO INTERDISCIPLINAR DA GUARDA COMPARTILHADA - DIREITO E PSICANÁLISE
}

\author{
Gita Goldenberg ${ }^{1}$ \\ Davi Salazar ${ }^{2}$ \\ Diego Vinícius Pinto da Rosa ${ }^{3}$ \\ Eduardo Quesada ${ }^{4}$
}

Este artigo é fruto da pesquisa intitulada "A importância da afetividade para a dignidade da pessoa humana". Considerando que a dignidade da pessoa humana engloba vários direitos, como a convivência familiar e comunitária e, considerando que estes melhor se realizam através da criação de laços afetivos entre as pessoas, temos que a dignidade da pessoa humana está muito mais para o ser humano em razão de sua subjetividade, do que para o sujeito de direitos, conceito este técnico e abstrato, titular tão apenas de um conjunto de direitos patrimoniais. Partindo disto, acreditamos que a dignidade humana pode ser pensada pelo discurso psicanalítico, consolidando-se a noção de desejo inconsciente e constatando-se que o discurso jurídico positivista não releva a falta constitutiva que impulsiona o sujeito para os seus próprios desejos ${ }^{5}$.

Esta dignidade, assim, é capaz de reestruturar os fundamentos do direito, na medida em que realiza, nas palavras de Gustavo Tepedino "processo de verdadeira inclusão social, com a ascensão à realidade normativa de interesses coletivos, direitos da personalidade e renovadas situações jurídicas existenciais, desprovidas de titularidades patrimoniais, independentemente destas ou mesmo em detrimento destas"

\footnotetext{
1 Professor Adjunto da Universidade do Estado do Rio de Janeiro, Brasil .Possui graduação em Psicologia pela Universidade Santa Úrsula (1979), mestrado em Psicologia Social e da Personalidade pela Universidade Federal do Rio de Janeiro (1981) e doutorado em Psicologia Social e da Personalidade pela Fundação Getúlio Vargas - RJ (1986). Psicanalista pela Sociedade Psicanálitica do Rio de Janeiro. Atualmente é professora da adjunto da faculdade de direito da Universidade do Estado do Rio de Janeiro

${ }^{2}$ Aluno de graduação do curso de Direito - UERJ

${ }^{3}$ Aluno de graduação do curso de Direito - UERJ

${ }^{4}$ Aluno de graduação do curso de Direito - UERJ Atualmente exerce a atividade de estagiário jurídico do Ministério Público do Estado do Rio de Janeiro

${ }^{5}$ PHILIPPI, Jeanine Nicolazzi. Reflexões acerca do sujeito do Direito. In Paravração Revista de Psicanálise. Ano II. No 02. Outubro. 1994. p. 177.

${ }^{6}$ TEPEDINO, Gustavo. Do sujeito de direito à pessoa humana. In Temas de Direito Civil - Tomo II. Rio de Janeiro: Renovar, 2006, p. 342.
} 
Para a elaboração do presente estudo contribuiu a Lei $n^{\circ}$. 11.698/08, que incluiu recentemente a guarda compartilhada no Código Civil. Entendemos que este modelo de guarda vem ao encontro da dignidade humana ao passo em que promove a afetividade, através de um maior convívio dos filhos com seus genitores. Ao primar pela importância da afetividade, o instituto da guarda compartilhada valoriza o princípio do melhor interesse da criança, que é também um desdobramento da referida dignidade. Este tema foi instigado por nós através do trabalho de campo realizado em Varas de Família, oportunidade em que estudamos vários processos atinentes à guarda, inclusive aqueles nos quais fora exarada sentença de guarda compartilhada. ${ }^{7}$

Entendemos que a afetividade tem embasamento constitucional, pois a família é vista como um grupo social fundado nos laços de afetividade ${ }^{8}$. Acompanhamos o pensamento do jurista Waldyr Grisard Filho ${ }^{9}$ quando este menciona que a ausência de um consenso dos pais quanto à solução de seus conflitos não induz obrigatoriamente à impossibilidade da guarda compartilhada. Com base principalmente no artigo 227 da Constituição, o autor afirma que este modelo de guarda faria jus aos princípios relativos à promoção de direitos como o lazer, a educação, a dignidade e a convivência familiar e comunitária, que certamente se coadunam com o princípio do melhor interesse da criança.

Anterior ao projeto que culminou no advento da Lei $n^{\circ} .11 .698 / 08$, o referido autor já propunha que a Constituição abarcava implicitamente a possibilidade da guarda compartilhada. Todavia, pela resistência existente no mundo jurídico e a ocorrência de divergências doutrinárias e jurisprudenciais acerca do instituto, pensamos que uma lei a respeito pode auxiliar em uma melhor elucidação dos processos judiciais, enquanto apresentar a afetividade como um ponto relevante nas questões conflituosas. Considerando que os filhos, mesmo após a separação dos pais, continuam necessitando do convívio de seus genitores, cremos ser importante este novo modelo de guarda, que poderá oferecer maior estabilidade afetiva para a formação psíquico-emocional.

\footnotetext{
${ }^{7}$ Não consideramos aqui, que as sentenças de guarda compartilhada sejam uma solução para os conflitos atinentes à ações de guarda, que eventualmente surjam quando os pais se separam. Compreendemos, entretanto, ser importante esta, na medida em que permite ao Judiciário reconhecer a relevância da convivência dos filhos com seus pais, favorecendo as relações afetivas e não legitimando apenas a guarda unilateral.

${ }^{8}$ Art. $1^{\circ}$, III, CF, art. 226 parágrafo $3^{\circ}$ e $4^{\circ}$ da $\mathrm{CF}$, além do artigo 227 parágrafo $6^{\circ}$.

${ }^{9}$ GRISARD FILHO, Waldir. Guarda compartilhada: um novo modelo de responsabilidade parental. São Paulo: Editora Revista dos Tribunais, 2000.
} 
Ante o exposto, merece discussão a recente lei da guarda compartilhada, Lei $\mathrm{n}^{\circ}$. 11.698/08, que reforça o afeto como elemento necessário para a guarda. Em primeira vista, a lei parece restringir o conceito de afetividade unicamente a guarda unilateral, isso se tomarmos tão somente a interpretação gramatical do dispositivo. Entretanto, entendemos que a guarda compartilhada enfatiza muito mais a afetividade, pois a própria lei prioriza este novo modelo de guarda, quando expõe que o mesmo será aplicado sempre que possível, ainda que sem o consentimento dos pais.

Assim, se o afeto é tido relevante para a guarda unilateral, certamente o será para a guarda compartilhada que é expressamente preferida pelo ordenamento jurídico. No mesmo contexto, os direitos à saúde, à segurança e à educação serão observados no estabelecimento da guarda compartilhada, todavia serão estes requisitos objetivamente adquiríveis, ao revés do afeto que requererá uma construção através do convívio e do predomínio principalmente das relações amorosas, que são o escopo da guarda compartilhada. Não raros são os casos em que os genitores possuem meios materiais de disponibilizar aos filhos segurança ou educação e, ainda assim, são incapazes de lhes proporcionar o afeto.

Resumindo o outrora explicado, valorizamos a nova redação do artigo $1.583^{10}$ do Código Civil que, ao elencar a guarda unilateral, destaca o afeto nas relações da criança com os seus genitores, porém, entendemos que tal assertiva poderia se repetir explicitamente na redação do artigo $1.584^{11}$ C.C., pois não é possível vislumbrar a guarda compartilhada despida de afeto.

\footnotetext{
${ }^{10}$ Art. 1.583. A guarda será unilateral ou compartilhada.

$\S 1^{\circ}$ Compreende-se por guarda unilateral a atribuída a um só dos genitores ou a alguém que o substitua (art. $1.584, \S 5^{\circ}$ ) e, por guarda compartilhada a responsabilização conjunta e o exercício de direitos e deveres do pai e da mãe que não vivam sob o mesmo teto, concernentes ao poder familiar dos filhos comuns.

$\S 2^{\circ}$ A guarda unilateral será atribuída ao genitor que revele melhores condições para exercê-la e, objetivamente, mais aptidão para propiciar aos filhos os seguintes fatores:

I - afeto nas relações com o genitor e com o grupo familiar;

II - saúde e segurança;

III - educação.

$\S 3^{\circ}$ A guarda unilateral obriga o pai ou a mãe que não a detenha a supervisionar os interesses dos filhos. $\S 4^{\circ}$ (VETADO).

11 Art. 1.584. A guarda, unilateral ou compartilhada, poderá ser:

I - requerida, por consenso, pelo pai e pela mãe, ou por qualquer deles, em ação autônoma de separação, de divórcio, de dissolução de união estável ou em medida cautelar;

II - decretada pelo juiz, em atenção a necessidades específicas do filho, ou em razão da distribuição de tempo necessário ao convívio deste com o pai e com a mãe.
} 
Em contrapartida, nas nossas reflexões acerca da lei da guarda compartilhada, ressaltamos algumas críticas através da leitura conjugada dos parágrafos $1^{\circ}$ e $4^{\circ}$ do artigo 1584 do referido Código. Estes dispositivos poderiam trazer a idéia de que a guarda compartilhada consistiria em uma modalidade de contrato por expressar os vocábulos "sanções" e "cláusula", imprimindo desta forma, nas relações familiares, o cunho frio das relações patrimoniais que independem da afetividade.

O legislador enfocou a necessidade de explicar a importância e o significado da guarda compartilhada no $\S 1^{\circ}$ do referido artigo, mas teria se equivocado ao estipular sanções ao cônjuge que abandona o filho afetivamente. Propomos que a lei poderia estimular o genitor que está em dificuldades de se coadunar à guarda compartilhada a fortalecer seus laços afetivos com seu filho e não somente puni-lo, visto que a penalidade da norma, além de alimentar o conflito (e não o afeto) poderia ainda incitar a manutenção do vínculo processual, ou seja, a sobreposição da relação hostil à relação amorosa em um litígio.

No que tange ao parágrafo $4^{\circ}$ do artigo 1584 , ao genitor que denigre a imagem do outro, não basta tão somente a diminuição do convívio deste com a criança, devendo haver também um trabalho de fortalecimento das relações de parentalidade a ser feito por equipe interprofissional, a fim de não se continuar prejudicando o contato do filho com o outro genitor.

Vemos como importante a estipulação do legislador, no $\S 3^{\circ}$ do mesmo dispositivo legal, da possibilidade de atuação de equipe interdisciplinar ou técnico profissional nas questões atinentes ao convívio dos pais com a criança, especialmente nos casos de guarda compartilhada. Esta poderá propiciar um maior entendimento dos pais de que os conflitos que

$\S 1^{\circ} \mathrm{Na}$ audiência de conciliação, o juiz informará ao pai e à mãe o significado da guarda compartilhada, a sua importância, a similitude de deveres e direitos atribuídos aos genitores e as sanções pelo descumprimento de suas cláusulas.

$\S 2^{\circ}$ Quando não houver acordo entre a mãe e o pai quanto à guarda do filho, será aplicada, sempre que possível, a guarda compartilhada.

$\S 3^{\circ}$ Para estabelecer as atribuições do pai e da mãe e os períodos de convivência sob guarda compartilhada, o juiz, de ofício ou a requerimento do Ministério Público, poderá basear-se em orientação técnico-profissional ou de equipe interdisciplinar.

$\S 4^{\circ}$ A alteração não autorizada ou o descumprimento imotivado de cláusula de guarda, unilateral ou compartilhada, poderá implicar a redução de prerrogativas atribuídas ao seu detentor, inclusive quanto ao número de horas de convivência com o filho.

$\S 5^{\circ}$ Se o juiz verificar que o filho não deve permanecer sob a guarda do pai ou da mãe, deferirá a guarda à pessoa que revele compatibilidade com a natureza da medida, considerados, de preferência, o grau de parentesco e as relações de afinidade e afetividade. 
nutrem mutuamente, via de regra, não possuem relação com seus filhos, ou seja, os conflitos parentais não se misturam com os conflitos conjugais. Tais profissionais estariam em melhores condições de analisar os casos concretos e, conseqüentemente, a subjetividade das partes, estimulando um fortalecimento das relações afetivas entre pais e filhos.

A explicitação da atuação da equipe interdisciplinar no Código Civil, mais especificamente no capítulo da "Proteção das pessoas dos filhos", é um avanço legislativo e demonstra que o instituto da guarda deve ser tratado não somente no âmbito jurídico, mas também, assim compreendemos, na psicanálise.

Com relação ainda à lei, precisamente no parágrafo $3^{\circ}$ do art. 1584, C.C, questionamos a expressão "período de convivência" por pretender regrificar o cotidiano dos pais e filhos. Acompanhamos o pensamento da psicanalista Françoise Dolto ${ }^{12}$, ao mencionar que tudo aquilo que há de afetivo entre pais e filhos ficará desumanizado se for regido por excessivas regras e dias fixos. Por outro lado, torna-se importante a regulamentação do convívio quando se tratarem de separações litigiosas ou ações de guarda conflituosas, pois é comum que um dos genitores use de pretextos para impedir que o outro tenha contato com o filho. Nestes casos, verificamos que na prática o juiz se utiliza da regulamentação de visitas, objetivando à aproximação do filho com o genitor denegrido. Veja-se que em tais ações, as questões subjetivas estão geralmente muito mescladas às objetivas e, neste caso, vislumbramos que um psicanalista poderá ter uma melhor escuta do discurso do sujeito do inconsciente e não apenas do sujeito do consciente.

Em nossa pesquisa observamos, por meio de entrevistas, que há psicólogos e assistentes sociais (alguns inclusive com formação psicanalítica) atuando nos tribunais, não somente na elaboração de laudos, mas no fortalecimento dos vínculos afetivos entre os pais e filhos. Pelas assistentes sociais foi revelado que visitas em domicílio só costumam se dar quando há suspeita de violência envolvendo a criança. Os profissionais entrevistados procuram estimular a visitação gradativa entre pais e filhos no tribunal, ainda que não seja o local mais apropriado, visando o fortalecimento dos laços afetivos com o objetivo de dar continuidade às relações dos pais com os filhos quando não convivem no mesmo lar.

\footnotetext{
${ }^{12}$ DOLTO, Françoise. Quando os pais se separam. Rio de Janeiro: Jorge Zahar Editor, 1989, p. 76.
} 
Outro dado levantado reside em que, a atuação dos psicólogos e assistentes sociais, via de regra, se dá em processos complexos, isto é, nos casos em que os conflitos emocionais se apresentam de forma crônica, havendo maior resistência das partes. Materialmente foram apontados como exemplos destes casos, os que tratam da regulamentação de visitas e da definição da guarda de crianças. Alguns destes profissionais esclareceram que solicitam a presença dos advogados nas entrevistas, a fim de evitar questões que causem prejuízo ao acordo entre as partes. A nosso ver a presença de advogados nestes momentos pode não ser ideal ante a possibilidade de se acirrar ainda mais o litígio, não se observando assim o melhor interesse da criança.

Observou-se o fato de os laudos ou estudos produzidos pela equipe interprofissional do Tribunal, geralmente evitarem desnecessárias colocações relativas às questões internas das partes, moderando-se inclusive a utilização de termos técnicos, no intuito de não se incitar maior conflito e um conseqüente prolongamento dos processos.

Nesse contexto, colocamos que o trabalho da mediação ${ }^{13}$ poderia vir mais ao encontro do estabelecimento do diálogo entre os pais e filhos, e entre os próprios genitores do que a mera realização de laudos pela equipe interprofissional. A partir daí entendemos que o psicanalista terá melhores condições de realizar o trabalho de mediação, pois será mais apto a lidar com a transferência, com as paixões, o sofrimento, a sexualidade, o amor, o ódio, enfim, os sentimentos vividos pelas partes que são projetados para o mediador.

Pelo todo, acreditamos ser de muita importância o fato de haver juízes que valorizam a participação das equipes interprofissionais nos processos, inclusive utilizando-se dos estudos para exarar sentenças. Apontamos que os laudos psicológicos ou os estudos sociais não devem ser usados como lei e sim como uma análise científica da parentalidade e da conjugalidade, permitindo que as relações afetivas interpessoais sejam compreendidas em diversos momentos

\footnotetext{
13 “Mediação: é o processo de gestão de controvérsias no qual um profissional - ou mediador - intervém de forma imparcial e neutra, facilitando a comunicação entre os envolvidos, com vistas à solução da disputa. Esta solução, de benefício mútuo será construída pelos próprios participantes, a partir da identificação de seus interesses e necessidades e será legitimada através de um acordo voluntário que consubstanciará o seu cumprimento. $\mathrm{O}$ mediador poderá ser de diferentes campos profissionais, distinguindo-se pelo fato de possuir capacitação teórica e metodológica específica.”. MARODIN, Marilene; BREITMAN, Stella. A prática da moderna mediação: integração entre a psicologia e o direito. In Aspectos psicológicos na prática jurídica. Campinas: Millennium Editora, 2002, p. 473.
} 
da vida dos genitores e dos filhos, principalmente nos desejos destes em conviverem com aqueles. É importante privilegiar os desejos da criança, bem como ouvi-la, sem atribuir a ela, entretanto, o papel de decidir com quem almeja ficar a fim de não reforçar conflitos edípicos ou sentimento de culpa frente à separação dos genitores.

Registramos em nosso trabalho de campo realizado nas Varas de Família, que aqueles que buscam respaldo no Judiciário geralmente confundem os conflitos parentais e conjugais, conturbando as relações afetivas entre pais e filhos. É por essa razão que se mostra de grande valia o trabalho desempenhado pela equipe interprofissional que tem a possibilidade de, no caso concreto, acompanhar mais profundamente os fatores psíquicos inconscientes existentes na vida das pessoas. O conhecimento desses profissionais pode dar aos pais uma oportunidade maior de ventilarem seus sentimentos, vislumbrando uma nova perspectiva acerca de seus papéis na vida de seus filhos.

É impossível afirmar com precisão que a intervenção de uma equipe da área interprofissional seja capaz de realizar o que a Justiça não puder, no entanto, com um árduo, contínuo e duradouro trabalho, em muito se pode contribuir. Nesse conjunto, o psicólogo e o assistente social não devem assumir uma posição substitutiva do Judiciário, visto que o estudo não é taxativo e determinante na resolução do caso, mas serve como importante instrumento no convencimento do juiz em sua decisão. Ressaltamos que em conflitos conjugais o Estado deveria manter cautela, pois erroneamente poderá julgar existir um culpado pelo conflito conjugal, o que caracterizaria uma intervenção excessiva na vida privada.

Nossos estudos identificaram uma significativa quantidade de ações judiciais relativas exclusivamente à pensão alimentícia. Estas ações, freqüientemente motivadas pelos conflitos já mencionados, na maior parte dos casos enfocam unicamente a questão patrimonial e ignoram a realidade emocional. Outrossim, as lutas intermináveis pela guarda também são reflexos desses conflitos que distanciam psiquicamente os pais de seus filhos. A busca é apenas pela sensação de vitória de um genitor sobre o outro, enquanto que aos filhos não cabe lugar na disputa senão o de "troféu".

Verificamos deste modo, que a separação do casal poderá gerar sentimentos depressivos pela perda de um ideal narcísico através da conjugalidade e também a perda de um ideal de estrutura familiar constituída pela tríade "pai-mãe-filho". Tais sentimentos poderão ser 
decorrentes da dependência e da culpa que um dos cônjuges inconscientemente nega sentir em relação ao outro. Neste sentido, afirmam a psicanalista Marilene Guimarães e a advogada Ana Cristina Guimarães:

\begin{abstract}
A separação rompe com a fantasia da completude narcísica com o outro (cônjuge). Que recursos terá cada genitor para restabelecer seu equilíbrio narcísico? Generalizando, poderíamos dizer que podem ser acionados mecanismos que favoreçam a elaboração do luto pela separação ou, em caso dessa impossibilidade, a criança muitas vezes pode vir a ser usada como complemento narcísico dos pais. ${ }^{14}$
\end{abstract}

Assim, quando essas configurações vinculares narcísicas e conflituosas não levarem em consideração a subjetividade da criança, esta poderá ficar em uma situação de desamparo afetivo e em um ambiente desfavorável ao seu desenvolvimento emocional. Daí constatamos que geralmente a negação da dependência conjugal é uma das causas que resultam na manutenção de um vínculo processual afetivo, ou seja, um prolongamento da relação através de um processo judicial.

\title{
CONSIDERAÇÕES INTERDISCIPLINARES A RESPEITO DE CASOS CONCRETOS
}

A título de ilustração citaremos estudos de casos concretos atinentes à guarda compartilhada com a participação de equipes interprofissionais. Frisamos que não pretendemos relatá-los na íntegra, tampouco apresentar simples resumos, mas sim expor uma leitura com base em nossas próprias reflexões.

A guarda compartilhada no caso em que um dos genitores denigre a imagem do outro.

\footnotetext{
${ }^{14}$ GUIMARÃES, Marilene Silveira; GUIMARÃES, Ana Cristina Silveira. Guarda - Um olhar interdisciplinar sobre casos judiciais complexos. In Aspectos psicológicos na prática jurídica. Campinas: Millennium Editora, 2002, p. 452.
} 
Trata-se de uma ação de guarda ajuizada pelo pai de duas crianças, de oito e cinco anos respectivamente, em face da mãe, a fim de preservar a guarda de fato já exercida e regulamentar a visitação materna. Nesta ação, a juíza se utilizou por três vezes de laudos periciais realizados pela equipe de psicólogos existente no tribunal.

Estes laudos concluíram à época pela importância da convivência da criança não só com o pai, mas também com a mãe, tendo enfatizado a relação de afeto da genitora com as crianças, o que veio a definir posteriormente a necessidade de uma visitação progressiva.

Os primeiros estudos careceram da manifestação da mãe, não necessariamente por ela ter se negado a fazê-lo, mas por não ter sido localizada. Ressaltamos o fato de que a psicóloga ter sugerido que a guarda provisória fosse dada ao pai, mas ainda assim considerado importante de a mãe ser ouvida no processo.

Passados mais de três anos da separação, o ex-casal ainda se encontrava totalmente avesso a qualquer possibilidade de diálogo. Magoados, não poupavam as crianças destes ressentimentos, fazendo severas críticas um ao outro na frente destas, sem se preocuparem com as consequiências psíquicas - em especial nos filhos - em um litígio interminável.

O pai, requerente, alegou ter sido casado com a requerida durante seis anos e que nos últimos meses de convívio, antes da separação, a mesma tentou afastá-lo das crianças através de condutas desonrosas e violentas. Este pai afirmou que a genitora não possuía condições psicológicas de criar os filhos, em razão de seu desequilíbrio emocional e suas atitudes explosivas. Posteriormente apresentou comprovações de que a sua ex-mulher teria participado de um filme pornográfico. Tal fato causou um impasse ao promotor 
e à magistrada, que ficaram receosos da condição da mãe vir a interferir desfavoravelmente no psiquismo das crianças. Entendemos que se os filhos não forem envolvidos nestas questões, a guarda da mãe não fica impedida, pois possivelmente não haverá o comprometimento psíquico das crianças.

A mãe ingressou no processo alegando que as informações prestadas pelo requerente eram falsas. Afirmou que seus filhos foram retirados de sua guarda e que atualmente se encontra impedida de vê-los, pois foi ameaçada de morte pelo ex-marido. Expôs que nunca ameaçou o pai das crianças, mas que, ao contrário, fora agredida por este. Reiterando o exposto nos laudos a mãe requereu a imediata regulamentação das visitas até a audiência.

O Ministério Público se manifestou a favor do regime de visitação progressiva que inicialmente ocorreria com o acompanhamento dos psicólogos do tribunal, momento em que a mãe teria contato diretamente com as crianças durante uma hora e meia.

Por decisão da magistrada, realizou-se o regime de visitação progressiva $^{15}$, tendo os psicólogos concluído que, na ocasião dos encontros, a mãe e as crianças mostravam-se bastante afetuosas entre si. Relataram ainda, que o pai das crianças se encontrava bastante amargurado com a separação do casal, e que apontava para a impossibilidade da mãe cuidar dos filhos. $\mathrm{O}$ genitor requereu, posteriormente, que o retorno ao convívio com a mãe fosse feito com cautela.

A juíza considerou que as crianças encontravam-se bem cuidadas e que o pai esforçava-se ao máximo para oferecer aos filhos uma vida digna. Amparando-se nos aspectos materiais da

\footnotetext{
${ }^{15}$ Entendemos que, na prática, esta visitação deve consistir em uma gradual, e não abrupta, aproximação do genitor com o filho.
} 
questão, ela enfatizou o fato de que as crianças estudavam em uma escola particular, na qual estavam adaptadas. Destacou que crianças possuíam plano de saúde e que o pai pagava a uma senhora para tomar conta delas enquanto trabalhava. Entretanto, alertou ao pai o mal que faz às crianças quando maltrata e humilha a figura da exmulher na frente delas. Entendeu também ser essencial que as visitações maternas continuassem acontecendo, mas advertiu que a mãe dos menores, da mesma forma, deveria poupar seus filhos das críticas ao ex-marido.

$\mathrm{Na}$ sentença, a magistrada ressaltou, com base no estudo psicológico, a importância, para as crianças, da retomada do convívio junto à mãe, pois que aquelas demonstravam afeto por ambos os genitores, sentindo falta também da figura materna.

Consideramos que foi interessante a pronunciação do Ministério Público ao valorizar a necessidade de acompanhamento progressivo por parte dos psicólogos, posicionando-se de acordo com o princípio do melhor interesse da criança.

A Magistrada, por fim, deferiu a guarda compartilhada no sentido de ampliar a visitação da mãe, fixando a residência na casa do pai, determinando que a mãe pegasse as crianças na escola e não na casa do deste, no intuito de evitar uma continuação do conflito.

Este caso nos levou a algumas reflexões. Chamou-nos a atenção o fato de que o pai pediu a guarda dos menores cominada com o estabelecimento de um regime de visitação para a mãe. A atitude do pai poderia representar a possibilidade deste pretender, a nível inconsciente, prolongar o vínculo com a genitora, buscando através dos filhos um complemento narcísico para não elaborar o luto da separação. Entendemos que o conflito apontado existe em grande parte por conta da falta de diálogo entre a mãe e o pai. Vale ressaltar que neste caso, mesmo havendo o litígio, a juíza decidiu pela a guarda compartilhada. 
No entanto, observamos que esta guarda compartilhada não se realiza de fato, ocorrendo, em verdade, uma visitação ampliada.

Apesar do avanço jurídico na aplicação da guarda compartilhada pelos tribunais, o que há, via de regra, é uma ampliação do regime de visitação.

A guarda compartilhada no caso em que um dos genitores sofre de epilepsia.

Um casal, separado após três anos de convivência, disputava a guarda da filha em comum. O pai alegou inicialmente que mãe e filha precisavam de cuidados especiais, pois a genitora sofria de epilepsia e a menor apresentava problemas cardíacos, tendo passado por procedimento cirúrgico pouco tempo depois do seu nascimento. Foi requerida a antecipação de tutela alegando-se que a mãe, detentora à época da guarda de fato, não possuía condições materiais de cuidar da criança. Cabe salientar a forte influência da avó paterna durante o processo. Esta, requerendo a guarda juntamente com o pai da criança, apresentava comportamento mais ativo do que o próprio filho, denotando a concretização do seu ideal edipiano.

A juíza de plantão imediatamente requisitou a busca e apreensão da menor, aceitando as alegações relativas à falta de condições da mãe em razão de sua epilepsia.

$\mathrm{Na}$ contestação, a mãe afirmou que a concessão da busca e apreensão de uma criança de apenas um ano e quatro meses não atendia aos pressupostos legais para a antecipação de tutela, posto que esta fora deferida baseando-se somente na palavra do pai e da avó paterna.

A advogada da mãe argumentou que a relação primitiva entre mãe e bebê era muito importante para a infante e a não observância 
disto poderia trazer prejuízos irreparáveis, em razão de a genitora não ter conseguido visitar a filha.

Após o Ministério Público ter se manifestado pela importância da manutenção dos laços familiares, foram elaborados laudos psicológico e social, a pedido da juíza, nos quais sugeriu-se que a guarda retornasse à mãe, considerando-se a gravidade do caso. Ambos os laudos foram favoráveis pela manutenção do vínculo da criança com a genitora. No mesmo sentido, testemunhou o neurologista da mãe da criança, que apontou para a total capacidade da mesma em exercer sua função materna, desde que devidamente acompanhada durante os períodos de crise.

Posteriormente, a patrona da mãe requereu a guarda provisória, tendo a advogada do autor solicitado a cessação da visitação materna. O último pedido fora negado, mantendo-se a visitação.

$\mathrm{Na}$ sentença, a juíza fez menção a trechos do estudo psicológico, valorizando a relação afetiva entre mãe e filha como elemento importante para a decisão. Não usando a epilepsia como um óbice à capacidade de exercer a maternidade, o juízo exarou sentença de guarda compartilhada e concluiu que, para melhor interesse da criança, a criança deveria retornar à residência da mãe, sendo definido o regime de visitação paterna quinzenal, no qual o pai buscaria a filha aos sábados e às quartas. O pai apelou da sentença, declarando ter melhores condições de criar a filha. $\mathrm{O}$ recurso foi negado.

Concluímos que é uma constante nas ações judiciais referentes à guarda a hipótese de o pai requerer a guarda da filha em conjunto com a avó paterna. Parece haver, nesse caso, uma relação simbiótica entre pai e avó paterna, na qual esta se coloca, ao nível da fantasia, na posição de mãe da sua neta. 
Chamou nossa atenção o fato da criança ter sido retirada bruscamente do convívio de sua mãe, por determinação judicial requerida pelo pai e pela avó paterna. Esta situação pode ter ocasionado uma violência psíquica não só à mãe, mas também à criança, ainda lactante.

Baseando-se nas reflexões sobre o caso e considerando a entrevista realizada com a advogada do autor, constatamos não haver guarda compartilhada entre os genitores e sua filha, mas sim um desejo de guarda compartilhada entre a avó paterna e o pai da criança. Tal situação acima deixou de existir, pois ao ser exarada sentença de guarda compartilhada, reverteu-se a situação fática, passando a guarda de fato da criança para a sua mãe, com a existência de um amplo regime de visitação para o pai.

A guarda compartilhada no caso em que há uma possível relação homoafetiva entre o pai do menor e o advogado.

Este processo refere-se à postulação de guarda de um menino, requerida por sua mãe, sob a alegação de que o pai o levara consigo e a impossibilitava de qualquer convívio com a criança. No decorrer da ação, constatou-se que a mãe que se omitia como tal. Ao revés, o pai era quem efetivamente estimulava a continuação do vínculo da criança com a família materna. Na inicial, a mãe do menino alegou que sempre conviveu com o filho e este, ao passar determinado tempo com o genitor, não mais retornou.

Apresentada a contestação pelo pai, este esclareceu que a criança estava residindo na casa de sua avó materna sem a companhia de sua mãe, pois esta já havia se mudado para outra residência com o novo companheiro. Assim, de acordo com o pai da criança, houve o consentimento da avó materna no momento em que ele levou consigo o seu filho, posto aquela já não possuía condições financeiras e psíquicas para os cuidados do seu neto. Uma das razões para a mudança da criança foi a constatação, pelo genitor, de que a mesma já não freqüentava a escola e passava por total falta de 
higiene, sofrendo de problemas como sarna, piolho e micoses. O pai ressaltou que sempre levava o menino à casa de sua avó materna, não impossibilitando qualquer visitação por parte da mãe.

Houve uma entrevista com o advogado do pai, que se mostrou bastante receptivo, aparentando interessar-se mais que apenas um profissional ao postular pelos interesses de seu cliente. Este constantemente deu ênfase ao fato de o pai ter melhores condições para cuidar do seu filho.

Neste processo, apenas um estudo social fora elaborado, não tendo a juíza se pronunciado acerca da necessidade de parecer psicológico. Na ocasião, a assistente social afirmou que a criança, sob os cuidados do pai, exercia atividade esportiva e acompanhamento terapêutico. Observou o fato da mãe, no momento de sua mudança, não ter levado consigo nenhum de seus dois filhos, o que consistiria talvez em um ato de abandono. Constatou, ainda, que a genitora não empreendia esforços para o convívio com o filho em questão. A assistente social, por fim, sugeriu a permanência da situação do menino, sob a guarda do pai, sugerindo a livre visitação deste com sua família materna.

A magistrada decidiu pela manutenção do domicílio da criança - em companhia do pai - e pelo amplo convívio do menino com sua mãe, exarando sentença de guarda compartilhada.

Fica aparente, pelo todo, a falta de desejo da mãe acerca da ampliação do convívio com seu filho, o que nos leva a compreender não restar configurada a guarda compartilhada de fato. A ausência da mãe nos cuidados e no cotidiano do filho nos fez pensar que seu intento ao ajuizar a ação era apenas patrimonial, com vistas a pensão alimentícia.

Em entrevista com o advogado do genitor este informou com maiores detalhes a situação atual da criança. Afirmou que o pai do menino, até o momento, não foi capaz de restabelecer sua vida afetiva e, dada a intimidade demonstrada entre o advogado e o pai do 
menino, cremos que ambos poderiam estar mantendo uma relação homoafetiva entre si. Pelo discurso apresentado, acreditamos que a guarda compartilhada era, na verdade, mantida entre os dois.

Mesmo a sentença determinando a guarda compartilhada entre a mãe e o pai da criança, entendemos que esta vem recebendo melhores cuidados com o pai e seu possível companheiro do que quando no convívio com sua mãe.

\section{Guarda compartilhada como forma de corroborar possíveis relações incestuosas a nível inconsciente.}

Neste caso, a mãe de um menino requereu a guarda compartilhada juntamente com o avô materno da criança, sob a alegação de que o pai do menino praticara abuso sexual contra o mesmo. A mãe da criança sustentava que, além da acusação de abuso - ao final do processo não comprovada - o pai do menor afastara-se deste e já não o assistia afetiva e financeiramente. A mãe do menino informou que manteve uma breve relação com o pai deste e que não residiram juntos, tendo ela continuado a morar com o avô materno durante o período de gravidez.

Acreditamos que, em relação à acusação de abuso sexual, a genitora poderia estar projetando no filho fantasias sexuais inconscientes suas, relativas ao seu ex-companheiro, pois que insistentemente informava ao juízo que seu filho apresentava linguajar e comportamento inadequados. Releva mencionar, em todo caso, que outra ex-esposa do pai da criança também havia movido uma ação acusando-o de abuso sexual contra os filhos que com ela o mesmo tivera. Esta ação foi julgada improcedente.

O pai da criança não demonstrou interesse em ter a guarda de seu filho, tendo sido inclusive declarado revel no processo. 
Os laudos psicológicos realizados constataram certa imaturidade da mãe da criança e reconheceram que esta apresentava o implícito desejo de intensificar a convivência do filho com o avô materno. A mesma deixou seu emprego e passou a viver com seu filho sob o sustento do avô materno, já aposentado e, à época, bem idoso. O discurso apresentado pela mesma visava claramente eliminar a existência do pai na vida do filho, substituindo-o pela figura do avô materno. Ao avô foram atribuídas todas as tarefas que se espera da figura paterna. Afirmou-se, explicitamente, que a criança projetava no avô materno a figura paterna e dele assimilava a orientação para sua formação.

A mãe do menor continuava a demonstrar fortemente sua dependência em relação ao seu próprio pai, insistindo em apresentar supostos fatos novos com relação ao filho. Alegando que o mesmo vinha se comportando de maneira estranha e imprópria para sua idade, a genitora dirigiu uma carta à defensora pública, que à época a acompanhava no caso, não se permitindo quaisquer pudores em relatar frases profundamente pejorativas supostamente ditas pela criança.

Chamou-nos a atenção o fato de a mãe ter constituído diversos advogados para o caso ao longo da ação, bem como ter ajuizado várias outras ações. No caso em questão, muitos estudos psicológicos foram elaborados, uns decorrentes de processos anteriores e outros do presente. Em todos o que se verificou mais claramente foi a mãe exaustivamente afirmar que sua vida, após a gravidez, se dirigia unicamente às necessidades do filho e que o pai, invariavelmente, não demonstrou-se interessado em recuperar seus laços com o mesmo.

O pai da criança compareceu a algumas entrevistas realizadas pelos psicólogos do Tribunal, tendo na oportunidade informado que 
sua relação com a mãe da criança foi deveras tumultuada. Apesar de manifestamente ter declarado desejar uma reaproximação com o filho, na prática, pouco esforço se verificou. Ressalte-se que a presença do pai na ação foi escassa, tendo muitas vezes se registrado o insucesso em notificá-lo dos atos processuais, o que aparenta verdadeiro desinteresse do mesmo com relação ao filho.

Agendada audiência na qual o pai do menor compareceu, restou homologado um acordo em que o mesmo entregava à mãe e ao avô materno da criança o direito de guarda, ao passo que esta passaria a ser compartilhada por estes dois últimos.

Nosso estudo sobre este caso não observou o que acreditamos ser a contribuição da guarda compartilhada, isto é, a aproximação do filho no convívio de seu pai, a fim de possibilitar maior participação e presença deste na vida da criança. Pareceu-nos, em verdade, que a guarda compartilhada propiciou, neste caso, uma possível realização de desejos edipianos ${ }^{16}$ entre a mãe da criança e o avô materno.

Ao pai da criança não ficou regulamentada qualquer visitação e, considerando não ter sido estimulado o convívio deste com seu filho, aparenta-nos ter ocorrido, na verdade, a destituição deste pai. O comportamento dos advogados que atuaram na ação também colaborou para o entendimento de que houve um afastamento desse pai, visto terem apresentado forte resistência ao estabelecimento da guarda compartilhada entre o genitor, a genitora e a criança. O juízo, ao homologar o acordo de guarda compartilhada da mãe com o avô materno, em alguma medida, fortaleceu o desinteresse do pai biológico em manter um vínculo afetivo com a criança.

Pensamos, portanto, tendo em vista o acervo de processos judiciais estudados, que a guarda compartilhada não há de se efetivar meramente pela decisão judicial que a determina.

\footnotetext{
${ }^{16}$ Neste caso, não houve a concretização, ou seja, a satisfação, da relação incestuosa entre a filha e o pai. Houve somente a realização de um desejo inconsciente a nível psíquico. Entendemos que a mãe, inconscientemente, realizou o desejo de ter um filho com seu próprio pai (fantasias edipianas).
} 
Esta, apesar de ser um instituto desejável pelos reconhecidos benefícios que pode propiciar, nem sempre é possível de se concretizar.

Vale ressaltar um estudo de caso no qual não se exarou sentença de guarda compartilhada por ter havido obstáculos em razão da manutenção de um vínculo processual afetivo. Entendemos que este vínculo consiste no deslocamento de uma relação afetiva para o Judiciário, onde as pessoas desejam permanecerem ligadas, mesmo que de modo predominantemente hostil. Tal fato se apresenta, via de regra, através da interposição de vários recursos em um dado processo, ou ainda, do ajuizamento de diversas ações em um mesmo caso, como separação litigiosa, alimentos, regulamentação de visitas, destituição do poder familiar e medida de busca e apreensão.

\section{Caso em que há inviabilidade da guarda compartilhada em} razão da manutenção de vínculo processual afetivo.

Este caso trata dessa típica manutenção, em que a mãe de três menores tentava impedir que o pai destes tivesse acesso aos filhos. O prejuízo deste conflito chegara a tal ponto que a conclusão da sentença foi a de manter a guarda única para a mãe das crianças cabendo ao pai apenas uma visitação quinzenal, apesar de os estudos psicológicos terem reconhecido que a mãe manipulava claramente o discurso dos filhos.

Os estudos psicológicos apontaram que o genitor se distanciou demasiadamente, permitindo que seu espaço fosse tomado pelo caráter possessivo e controlador da mãe. Tratava-se de um pai extremamente ausente afetivamente, no sentido de não lutar pelos filhos, tendo expressado que perante os obstáculos conjugais estaria disposto a "desistir" dos mesmos. Este caso fora permeado de várias ações movidas, tanto pelo pai, quanto pela mãe das crianças.

Nos estudos mencionados, percebeu-se que a mãe compreendia os filhos como própria continuação sua, numa relação 
simbiótica a nível inconsciente, o que obviamente não os favorecia, pois não havia oportunidade para ao desenvolvimento da subjetividade das crianças. Estas estavam ligadas à mãe por uma relação afetiva baseada no medo e isto impossibilitava a independência psíquica, dificultando a convivência com o pai e outros familiares. $\mathrm{O}$ discurso da mãe nitidamente denegria a figura do genitor, no manifesto intuito de aliená-lo parentalmente.

Na sentença, o juízo reconheceu estarem claros os obstáculos que a mãe interpunha para a visitação do pai às crianças, restando estipulada a obrigação ao pagamento de multa ${ }^{17}$, para cada recusa da mãe no encontro do genitor com os filhos. Determinou-se ainda, que na inocorrência da visitação do pai por quaisquer razões, esta deveria ser compensada na semana ou data festiva seguinte ao acontecimento do fato.

Nesse caso, pôde-se verificar que a intervenção do Judiciário não foi capaz de fortalecer as relações afetivas entre pais e filhos ou mesmo modificar a dinâmica daquele núcleo familiar. Mostra-se, portanto, a impossibilidade de se exarar uma sentença de guarda compartilhada, bem como se promover a reestruturação das famílias unicamente por decisões judiciais. Assim é, pois nem sempre as relações afetivas se dão com base no vínculo amoroso, podendo haver também a predominância de relações hostis.

\section{CONSIDERAÇÕES FINAIS}

A partir dos nossos estudos e dos processos pesquisados nas Varas de Família, defendemos a guarda compartilhada, por esta favorecer a convivência familiar e,

${ }^{17}$ No caso em questão, o termo "multa" diz respeito ao encargo de natureza pecuniária que visa punir o pai quando este não cumpre com o dever de visitação. Por outro lado, entendemos que a multa pode ser, não somente de natureza pecuniária, mas conforme afirma Françoise Dolto: “...uma multa de tempo, a ser paga conforme as possibilidades geográficas, o afastamento uns dos outros" DOLTO, Françoise. Quando os pais se separam. Rio de Janeiro: Jorge Zahar Editor, 1989, p. 54. 
conseqüentemente, a continuidade da afetividade das crianças com seus pais, mesmo quando separados. A situação pós-divórcio não deve ser apresentada à criança como uma situação de abandono de um dos pais em relação a ela.

Entendemos que a guarda unilateral pode colaborar para a criança experimentar sentimentos de rejeição e baixa auto-estima. Há eventualmente uma diminuição da disponibilidade de relacionamento com o genitor que deixa de morar com a criança. Em contrapartida, a noção de guarda compartilhada compreende o reasseguramento da convivência na relação entre pais e filhos nos processos em que há disputa de guarda, prescindindo de uma regulamentação excessiva tal como é a regulamentação de visitas geralmente exarada pelos tribunais. De acordo com o jurista Waldir Grisard Filho:

A guarda compartilhada reflete o maior intercâmbio de papéis entre o homem e a mulher, aumenta a disponibilidade para os filhos, incentiva o adimplemento da pensão alimentícia, aumenta o grau de cooperação, de comunicação e de confiança entre os pais separados na educação dos filhos. Isso lhes permite discutir os detalhes diários da vida dos filhos, como pressuposto do novo modelo. ${ }^{18}$

Os pais devem exercer o poder familiar em consonância com a participação efetiva na vida do filho, não só no âmbito das necessidades materiais (como educação, lazer, alimentação), mas também quanto a questões subjetivas (sentimentos, desejos, relações interpessoais).

Equivocadamente vêm se entendendo que a criança deve residir por períodos idênticos, ora na casa do pai, ora na casa da mãe, confundindo-se o conceito de guarda alternada com o de guarda compartilhada. No entanto, o diferencial entre guarda alternada e guarda compartilhada é que esta, além de permitir uma "nova configuração social de mudança de papéis na família, com o pai se tornando mais participante na vida dos filhos, possibilita que, além de provedores, eles também desejem permanecer guardiões dos filhos quando a família

\footnotetext{
${ }^{18}$ GRISARD FILHO, Waldir. Guarda compartilhada: um novo modelo de responsabilidade parental. São Paulo: Editora Revista dos Tribunais, 2000, p. 160.
} 
se transforma pela separação". ${ }^{19}$ Cremos ser importante a fixação de uma residência referencial na casa de um dos genitores para a estabilidade emocional do filho, mas a escolha deve ser feita de acordo com o desejo da própria criança.

Acreditamos que pode haver guarda compartilhada ainda na hipótese de famílias homoafetivas. A jurisprudência, inclusive, já aponta a possibilidade da convivência de crianças com companheiros do mesmo sexo, com base no princípio do melhor interesse da criança, privilegiando desta forma o que há de mais importante entre pais e filhos, que é a afetividade. Neste sentido, a guarda compartilhada independe do sexo biológico dos pais.

Pensamos, ademais, que a viabilidade da aplicação concreta da guarda compartilhada é maior quando há discernimento entre os conflitos da conjugalidade e da parentalidade. Conflitos conjugais decorrentes da separação são freqüentes, mas não significam a impossibilidade da aplicação da guarda compartilhada quando os pais exercem bem a função materna e paterna. A função materna compreende os cuidados à criança relacionados às primeiras necessidades e desejos desta. A função paterna consiste na introdução da lei simbólica, com um conseqüente rompimento da relação dual do filho com o genitor que exerce a função materna, possibilitando um limite na relação incestuosa de natureza edipiana. Isto permite à criança perceber que não é um complemento da "mãe", passando a ter seu próprio desejo. Apesar da noção histórica de que a mãe é responsável pela função materna, o pai também pode vir a exercer esta função, na medida em que promova os cuidados pertinentes às primeiras necessidades e desejos do filho. Isto não impede ao pai, posteriormente, de exercer a função paterna na introdução da lei simbólica.

Ressaltamos que uma das funções da equipe interdisciplinar é justamente explicar para os pais o funcionamento da guarda compartilhada e como ela pode ser um meio de melhorar as relações subjetivas entre pais e filhos. Entretanto, entendemos que em alguns casos o acompanhamento da visitação progressiva ${ }^{20}$ já estimula a guarda compartilhada, ainda que implicitamente. Tal circunstância vem ao encontro do que observamos em nossos estudos, isto é, alguns juízes valorizam a participação do assistente social e do psicólogo como

\footnotetext{
${ }^{19}$ GUIMARÃES, Marilene Silveira; GUIMARÃES, Ana Cristina Silveira. Guarda - Um olhar interdisciplinar sobre casos judiciais complexos. In Aspectos psicológicos na prática jurídica. Campinas: Millennium Editora, 2002, pp. $447-470$.

${ }^{20}$ Entendemos por visitação progressiva, o encontro gradual dos filhos com seus pais, acompanhado por um profissional do Tribunal.
} 
coadjuvantes na busca por uma compreensão mais profunda das relações interpessoais presentes em cada caso.

Acreditamos que os casos mais difíceis de se concretizar a guarda compartilhada efetivamente são aqueles nos quais predomina um deslocamento da relação afetiva para um vínculo processual afetivo. A princípio a guarda compartilhada, quando existe um conflito acirrado, pode ser inábil. Todavia, a sentença que decidir pela guarda compartilhada eventualmente facultará alguma aproximação dos pais e filhos, mesmo que sob a forma de uma ampliação da visitação. Neste sentido, sugerimos um acompanhamento interprofissional posterior ao processo, como meio de averiguar a evolução da guarda compartilhada e auxiliar as partes a fim de encontrarem meios para tentar solucionar ocasionais conflitos.

Constatamos, com base nas entrevistas realizadas com os advogados dos casos estudados, que ainda há uma considerável resistência ao instituto da guarda compartilhada, tanto pelas partes como pelos próprios advogados. Isto pois, a maioria dos profissionais permanece arraigada a uma cultura jurídico-processual ligada aos conceitos de êxito e derrota, não buscando desta forma o melhor interesse da criança.

A guarda compartilhada, ao mesmo tempo em que promove a realização dos preceitos constitucionais sobre a família, no campo subjetivo propicia a formação emocional da criança através do estímulo à convivência desta com seus genitores, trazendo para todos na relação o mais puro enriquecimento de suas vidas. $\mathrm{O}$ entendimento da afetividade, do ponto de vista psicanalítico, certamente contribuirá para a compreensão da guarda compartilhada e sua relevância nas relações familiares, algo que a letra da lei eventualmente não será capaz de alcançar. Assim é, porque muitas vezes o Judiciário não consegue adentrar na esfera dos desejos das partes, levando em consideração apenas a possibilidade do guardião atender às necessidades objetivas dos filhos. Conforme afirma Maria Antonieta Pisano Motta:

Insistimos em que a guarda compartilhada deve ser tomada antes de tudo como um conceito, uma postura diante dos filhos de pais separados, reconhecendo sua necessidade de um relacionamento ininterrupto com ambos os pais que se encontram numa posição 
central e igualitária para o desenvolvimento da saúde física e psicológica de seus filhos ${ }^{21}$.

Concluímos que guarda compartilhada está intimamente ligada ao princípio do melhor interesse da criança, porquanto tem a finalidade de protegê-la e possibilitar seu desenvolvimento afetivo como pessoa plena a partir de sua família. E que assim seja porque, resguardar a formação da criança é sem dúvida uma promoção direta do Princípio da Dignidade da Pessoa Humana.

\section{REFERÊNCIAS BIBLIOGRÁFICAS}

BRITO, Rodrigo Toscano de. Situando o direito de família entre os princípios da dignidade humana e da razoável duração do processo. In Belo Horizonte: IBDFAM, 2006, pp. 819 841.

COSTA, Jurandir Freire. Família e dignidade. In Belo Horizonte: IBDFAM, 2006, pp. $15-28$.

DOLTO, Françoise. Quando os pais se separam. Rio de Janeiro: Jorge Zahar Editor, 1989, p. 76.

FREUD, Sigmund. Inibições, Sintomas e Ansiedade. In Um estudo autobiográfico. Vol. XI, Rio de Janeiro: Editora Imago, 1926, pp. 79 - 171.

. Três ensaios sobre a teoria da sexualidade. In Um caso de histeria e três ensaios sobre sexualidade. Rio de Janeiro: Editora Imago, 1905, pp. 117 - 218.

Cinco lições de psicanálise. In Cinco lições de psicanálise. Rio de Janeiro: Editora Imago, 1910, pp. $15-73$.

\footnotetext{
${ }^{21}$ MOTTA, Maria Antonieta Pisano. Guarda Compartilhada: Novas soluções para novos tempos. Disponível em: <http://www.apase.org.br/91001-gcnovassolucoes.htm> Acesso em: 15 de março de 2008.
} 
A dissolução do complexo de Édipo. In O Ego e o Id. Rio de Janeiro: Editora Imago, 1924, pp. $189-201$.

GRISARD FILHO, Waldir. Guarda compartilhada: um novo modelo de responsabilidade parental. São Paulo: Editora Revista dos Tribunais, 2000, p. 160.

GUIMARÃES, Marilene Silveira; GUIMARÃES, Ana Cristina Silveira. Guarda - Um olhar interdisciplinar sobre casos judiciais complexos. In Aspectos psicológicos na prática jurídica. Campinas: Millennium Editora, 2002, pp. 447 - 470.

KERNBERG, Otto F. Psicopatologia das relações amorosas. Porto Alegre: Artes Médicas, 1995.

MARODIN, Marilene; BREITMAN, Stella. A prática da moderna mediação: integração entre a psicologia e o direito. In Aspectos psicológicos na prática jurídica. Campinas: Millennium Editora, 2002, pp. $471-488$.

MOTTA, Maria Antonieta Pisano. Compartilhando a guarda no consenso e no litígio. In . Belo Horizonte: IBDFAM, 2006, pp. $591-602$.

NAZARETH, Eliana Riberti. Com quem fico, com papai ou com mamãe? Disponível em <http://www.cerema.org.br/artigos/comquem.html >. Site pesquisado em 04.03.2008.

PEREIRA, Rodrigo da Cunha. Uma principiologia para o direito de família. In Família e Dignidade Humana / Anais V Congresso Brasileiro de Direito de Família. Belo Horizonte: IBDFAM, 2006.

PHILIPPI, Jeanine Nicolazzi. Reflexões acerca do sujeito do Direito. In Paravração Revista de Psicanálise. Ano II. No 02. Outubro. 1994. p. 177. 
TEPEDINO, Gustavo. Do sujeito de direito à pessoa humana. In Temas de Direito Civil Tomo II, Rio de Janeiro: Renovar, 2006, pp. 340 - 342.

A disciplina da guarda e a autoridade parental na ordem civil - constitucional. In , Rio de Janeiro: Renovar, 2006, pp. 173 - 191. 